\title{
Cleavage of eukaryotic translation initiation factor 4GII correlates with translation inhibition during apoptosis
}

\author{
WE Marissen ${ }^{1,3}$, A Gradi ${ }^{2}$, N Sonenberg ${ }^{2}$ and RE Lloyd ${ }^{\star, 3}$ \\ ${ }^{1}$ Department of Microbiology \& Immunology, University of Oklahoma Health \\ Sciences Center, Oklahoma City, Oklahoma, OK 73104, USA \\ 2 Department of Biochemistry and McGill Cancer Center, McGill University, \\ Montreal, Quebec, Canada \\ ${ }^{3}$ Department of Molecular Virology and Microbiology, Baylor College of \\ Medicine, Houston, Texas, TX 77030, USA \\ * Corresponding author: RE Lloyd, Department of Molecular Virology and \\ Microbiology, Baylor College of Medicine, Houston, Texas, TX 77030, USA \\ Tel: 713-798-8993; Fax: 713-798-5075; E-mail: rlloyd@bcm.tmc.edu
}

Received 26.4.00; revised 21.6.00; accepted 1.8.00

Edited by BA Osborne

\begin{abstract}
Eukaryotic translation initiation factor 4G (elF4G), which has two homologs known as elF4GI and elF4GIl, functions in a complex (elF4F) which binds to the $5^{\prime}$ cap structure of cellular mRNAs and facilitates binding of capped mRNA to 40S ribosomal subunits. Disruption of this complex in enterovirusinfected cells through elF4G cleavage is known to block this step of translation initiation, thus leading to a drastic inhibition of cap-dependent translation. Here, we show that like elF4GI, the newly identified homolog elF4GII is cleaved during apoptosis in HeLa cells and can serve as a substrate for caspase 3. Proteolysis of both elF4GI and elF4GII occurs with similar kinetics and coincides with the profound translation inhibition observed in cisplatin-treated HeLa cells. Both elF4GI and elF4GIl can be cleaved by caspase 3 with similar efficiency in vitro, however, elF4Gll is processed into additional fragments which destroy its core central domain and likely contributes to the shutoff of translation observed in apoptosis. Cell Death and Differentiation (2000) 7, 1234-1243.
\end{abstract}

Keywords: translation initiation factor; elF4G; caspase; apoptosis; protein synthesis inhibition

Abbreviations: CHAPS, \% 3-[(3-cholamidopropyl)dimethyl-ammonio]-1-propanesulfonate; $\mathrm{CHO}$, aldehyde; elF, eukaryotic initiation factor; FITC, fluorescein isothiocynate; PARP, poly-(ADP ribose) polymerase; pNA, para-nitroanilide; TNF $\alpha$, tumor necrosis factor alpha; Z-VAD-FMK, benzyloxycarbonyl, VAD-fluoromethylketone

\section{Introduction}

Apoptosis or programmed cell death is now recognized as a natural mechanism to remove damaged or even virus-infected cells from tissues. It has been known for some time that translation is inhibited in apoptotic cells but potential mechanisms of this inhibition have not been investigated until recently. The components of the apoptotic machinery, i.e. the caspases, are already present in the cell, and therefore, de novo protein synthesis is not required for induction of apoptosis in most systems. ${ }^{1-4}$ However, there are several other systems in which protein synthesis is required for apoptosis to occur. ${ }^{5-8}$ In addition, drastic inhibition of cellular translation in virus-infected cells has long been considered a major mechanism of cell death. Therefore, regulation of translation could potentially play an important role in the induction or execution of apoptosis.

Eukaryotic translation initiation factor $4 \mathrm{~F}$ (elF4F) is required for binding the vast majority of capped mRNAs to ribosomes during the initial steps of translation. elF4F consists of elF4E, the cap-binding protein that specifically binds to the $5^{\prime}$ cap structure $\left(\mathrm{m}^{7} \mathrm{GpppN}\right)$ present on cellular mRNAs; elF4A, an ATP-dependent RNA helicase; and elF4G which functions as a molecular scaffold by simultaneously binding elF4E, elF4A, elF3. ${ }^{9,10}$ Simultaneous binding of elF3 with elF4G and the $40 S$ ribosomal subunit, is thought to enable ribosomes to bind capped mRNAs and initiate protein synthesis. Numerous studies with picornaviruses have shown that cleavage of elF4G results in functional disruption of the elF4F protein complex coincident with inhibition of translation. ${ }^{10-13}$ Cleavage of elF4G results in production of two fragments, an $\mathrm{N}$-terminal fragment containing the binding site for elF4E and a Cterminal fragment bearing the binding site for elF3 and elF4A, ${ }^{9}$ thus separating domains responsible for binding capped mRNA (via elF4E) and the ribosome (via elF3). This is thought to result in drastic impairment of capdependent translation. Further, the rapid and drastic inhibition of cap-dependent translation during picornaviral infection has long been thought to be very important mechanism by which infected cells die. Recently, Goldstaub et $\mathrm{al}^{14}$ demonstrated that the expression of 2Apro in mammalian cells was sufficient to induce programmed cell death.

Recently, we discovered that elF4GI was cleaved during apoptosis in a variety of cell types and that its cleavage correlated with translation inhibition in apoptotic cells. ${ }^{15}$ elF4GI was the first mammalian translation factor found to be targeted during apoptosis and its degradation could account for much of the observed inhibition of protein synthesis in apoptotic cells. Recently, a new functional homolog of elF4GI, named elF4GII, was identified that is $46 \%$ identical to elF4GI, which binds to elF4E, elF4A, elF3, and is capable of restoring cap-dependent translation in vitro after degradation of elF4G. ${ }^{16}$ Although the functional relevance of two elF4G isoforms is currently not known, the presence of two forms of elF4G has been conserved throughout evolution and can be observed in other species, including yeast, ${ }^{17}$ and plants. ${ }^{18}$ Intriguingly, in poliovirusinfected cells proteolysis of elF4GII, but not elF4GI, seems to correlate better with the observed translation inhibition. ${ }^{19}$ 
This may suggest that significant functional differences between the two forms of elF4G do exist, yet more experiments need to be performed to elucidate those.

Here, we show that cleavage of elF4GII coincides with elF4GI cleavage in apoptotic cells and correlates with translation inhibition in cisplatin-treated HeLa cells. Interestingly, whereas elF4Gl is cleaved into only three fragments, ${ }^{15}$ elF4GIl appears to be cleaved by caspase 3 at multiple sites. Taken together, our results show cleavage of elF4GIl during apoptosis, thus providing an additional event which contributes to the mechanism of translational control during apoptosis.

\section{Results}

\section{In vivo cleavage of elF4GII}

After our observation that elF4GI was cleaved during apoptosis with kinetics which correlated with translation inhibition, ${ }^{15}$ we wanted to determine the fate of elF4GII during apoptosis. Therefore, apoptosis was induced in $\mathrm{HeLa}$ cells by treatment with $100 \mu \mathrm{M}$ cisplatin, and monitored over a $16 \mathrm{~h}$ period. Cleavage of elF4GIl was analyzed by immunoblot using a N-terminal specific elF4GII antibody (produced with a fragment of elF4GIl comprising aa 445-604), and indicated by elF4GII ${ }_{N}$. The data (Figure $1 \mathrm{~A}$ ) show that elF4GII was rapidly cleaved in apoptotic cells, producing a dominant cleavage product of $97 \mathrm{kDa}$ which could be detected by $3 \mathrm{~h}$ (Figure 1A) and less abundant products near 150, 120 and $82 \mathrm{kDa}$. Immunoblots using this antibody suggested that while cleavage of elF4GIl began by $3 \mathrm{~h}$, uncleaved elF4GII was still detectable until $8-9 \mathrm{~h}$. Figure $1 \mathrm{~B}$ is an immunoblot showing elF4GI cleavage kinetics from the same experiment shown in Figure 1A. Comparison of the kinetics of elF4GI and elF4GIl cleavage shows an overall similarity in their cleavage rates, however, although elF4GI cleavage was detected one hour later than elF4GIl cleavage, it seemed to reach completion more abruptly. It should be pointed out that comparison of immunoblots from numerous experiments revealed no consistent major differences in the kinetics of cleavage of elF4GI and elF4GIl; they were essentially the same in most experiments, and minor variations are likely attributable to differential reactivity of antisera with antigens. The kinetics of cleavage of PARP, a well known cellular substrate of caspase 3 , were also examined and suggest activation of caspases correlates well with the cleavage of elF4GII. Therefore, cleavage of elF4GII occurs simultaneously with caspase-3 dependent cleavage of elF4GI and PARP. When apoptotic cells were measured by staining with annexin-FITC (Caltag) and immunofluorescence microscopy, we determined that the percentage of apoptotic cells were 2 , 39,77 and $98 \%$ at $0,4,8$ and $16 \mathrm{~h}$ respectively. Taken together, this correlation with PARP cleavage and annexin staining suggests that under these conditions elF4GIl cleavage occurs relatively late during the execution phase of apoptosis.

Previously, we demonstrated that elF4GI cleavage correlated with a decline in mRNA translation rates in vivo. Here, comparison of pulse label experiments (Figure $1 C)$ with immunoblot results revealed that the progressive cleavage of intact elF4GII also correlates with the observed drop in translation. In fact, the combined decline in both forms of elF4G may account for much of the inhibition in translation observed here, although modification of other
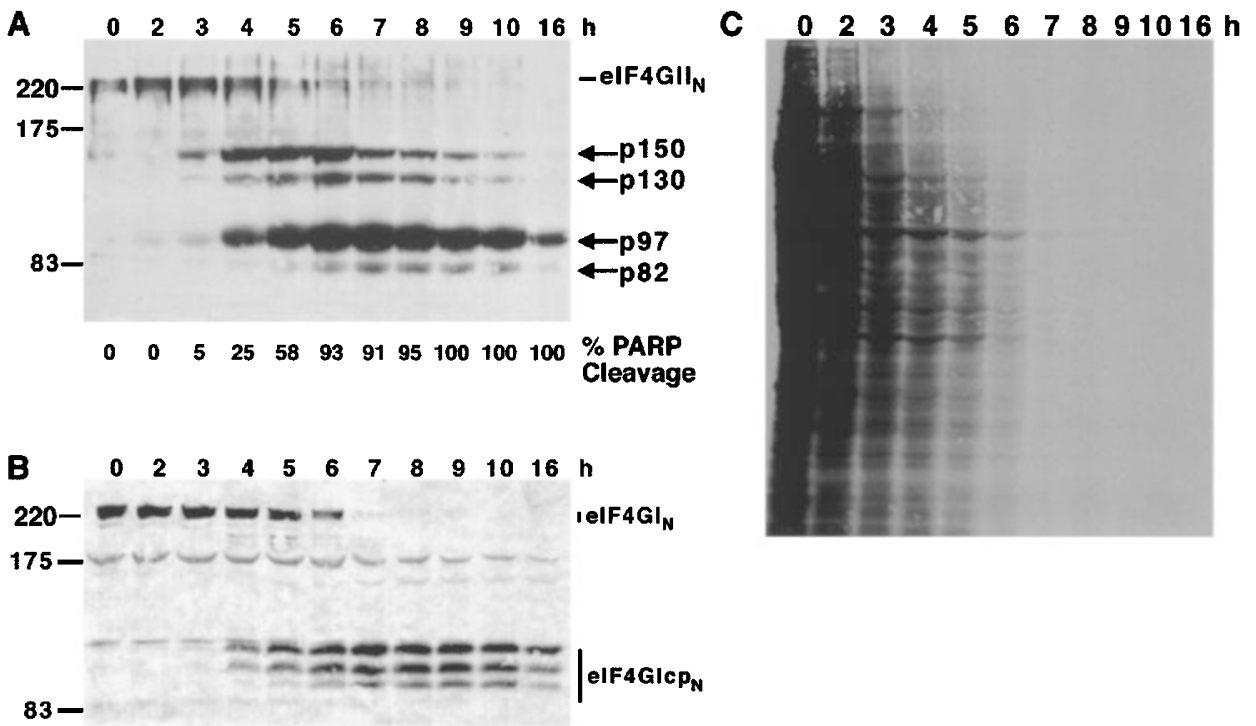

Figure 1 Kinetics of elF4GI and elF4Gll cleavage during apoptosis in HeLa cells. (A) HeLa cells were treated with $100 \mu$ M cisplatin and incubated for the indicated time periods. Cell lysates (50 $\mu \mathrm{g}$ of protein) were loaded on a $7 \%$ acrylamide gel and immunoblotted with polyclonal antiserum specific for $\mathrm{N}$-terminal elF4GII. elF4GII and cleavage products of elF4GII are indicated by arrows on the right. Molecular weight markers are indicated on the left. The per cent cleavage of PARP detected at each timepoint is shown below the panel. (B) Cell lysates ( $50 \mu \mathrm{g}$ of protein) as described in (A) were loaded on a $7 \%$ acrylamide gel and immunoblotted with polyclonal antisera specific for N-terminal elF4GI. elF4GI and cleavage products of elF4GI are indicated by arrows on the right. (C) After treatment with cisplatin for the time points (in hours) indicated, HeLa cells were pulse-labeled with [ ${ }^{35}$ S]-methionine for $1 \mathrm{~h}$, lysed, subjected to $12 \%$ SDS-PAGE, and analyzed by autoradiography 
translation factors (e.g. elF2 $\alpha$, [Marissen, 2000 \#3725]) is also occurring and likely contributes to translation regulation. Thus, we have now shown that both elF4GI and elF4GII are cleaved during apoptosis, and degradation of each could potentially contribute to inhibition of capdependent protein synthesis during apoptosis.

To further analyze the proteolytic processing of elF4GII, we also used a different antibody directed against a Cterminal portion of elF4Gll (aa 1168-1192), indicated by elF4GII ${ }_{C}$ (Figure 2). Cell lysates derived from the same experiment described in Figure 1 were analyzed by immunoblot, which again revealed complete cleavage of elF4Gll by $7 \mathrm{~h}$ after induction of apoptosis. The cleavage pattern of immunoreactive polypeptides included several potential transient cleavage products (p140, p120 and p58), which seem to accumulate into possible end products of 48,35 and $28 \mathrm{kDa}$ by $8 \mathrm{~h}$. Putative cross-reactive polypeptides which migrate near 65,60 and $34 \mathrm{kDa}$ are also sometimes detected with this antisera, the latter is often degraded in apoptosis as well. Apparently, the elF4GIl cleavage fragments are not very stable as they often disappeared between 10-16 h after induction of apoptosis. In general, degradation of elF4GII seemed to be more drastic and complete than elF4GI, whose three major cleavage products appear to be more stable, ${ }^{15}$ (data not shown). Overall, analysis of elF4GIl cleavage using two different antibodies directed against either N- or C-terminal region of elF4GIl reveals that elF4GII is cleaved into multiple fragments during apoptosis, and indicates several cleavage sites are utilized to degrade elF4GII.

\section{In vivo inhibition of elF4GIl cleavage}

To test whether elF4GIl cleavage is caspase-dependent, HeLa cells were pretreated for $1 \mathrm{~h}$ with the broad spectrum caspase inhibitor benzyloxycarbonyl-VAD-fluoromethylketone (Z-VAD-fmk) before administration of various apoptosis-inducing agents (Figure $3 \mathrm{~A}$ ). Treatment of HeLa cells with cisplatin resulted in cleavage of elF4Gll resulting in similar

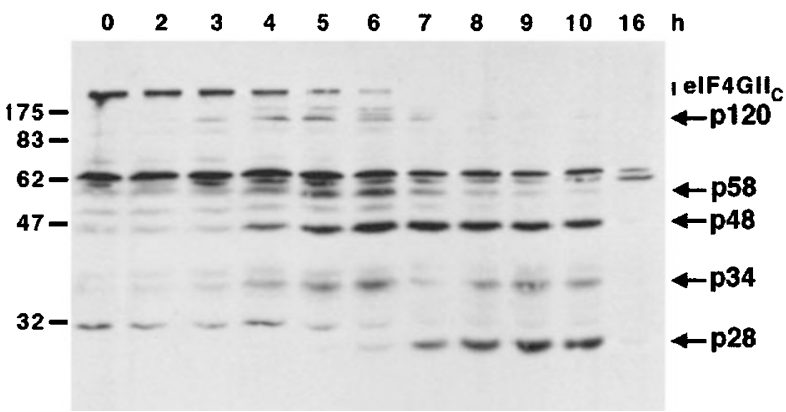

Figure 2 Analysis of elF4GIl cleavage during apoptosis using C-terminus specific elF4GII antibody. Cell lysates described in Figure 1 were subjected to SDS-PAGE (12\% acrylamide gel), and analyzed by immunoblotting with a antibody specific for the C-terminal portion of elF4GII. elF4GII and cleavage products of elF4GII are indicated by arrows on the right. Molecular weight markers are indicated on the left. Immunoreactive bands at near $62 \mathrm{kDa}$ are likely unrelated proteins which cross-react with this antisera. The identity of p34, which could be a minor alternate processing intermediate or an unrelated cross-reactive protein, has not been determined fragments as shown in Figure $1 \mathrm{~A}$ (using the $\mathrm{N}$-terminal specific antibody). In addition, treatment with etoposide or TNF $\alpha$ also led to cleavage and processing of elF4GII into the p97 cleavage fragment, indicating that cleavage of elF4GII may be a common event during apoptosis generated by several types of inducers, producing similar fragments. Regardless of which apoptotic inducer was used, cleavage of elF4GIl could be blocked by pretreatment of cells with $75 \mu \mathrm{M}$ Z-VAD-fmk. This suggests that activation of caspases is a necessary event for the induction or catalysis of elF4GII cleavage in apoptotic cells. Analysis of control cells (Figure $3 A$, lane $C$ ) revealed an apparent sporadic partial degradation of elF4GII (evidenced by a p150 cleavage product) that was not accompanied by detectable elF4GI degradation or PARP cleavage (data not shown). This was observed many times but did not correlate with increased presence of apoptotic cells in the culture and is possibly due to another unknown form of degradation.

Figure $3 \mathrm{~B}$ shows that caspase 3-related activity can be detected in cell lysates by cleavage of DEVD-pNA substrate and pretreatment of cells with Z-VAD-fmk caspase-inhibitor significantly inhibited the degree of

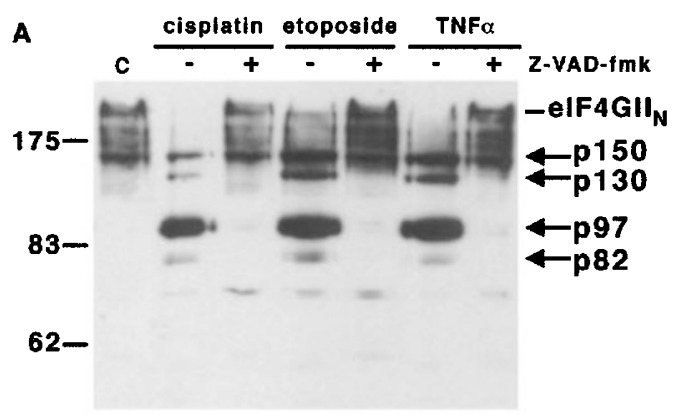

B

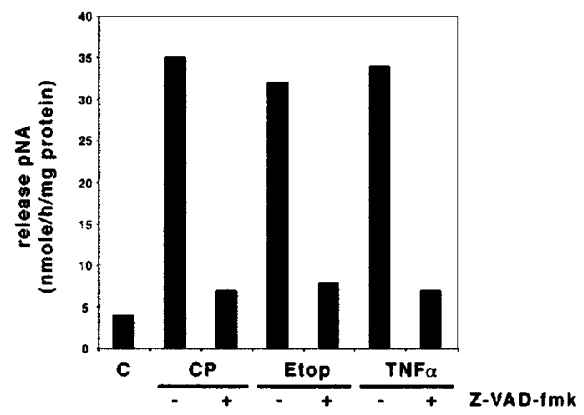

Figure 3 In vivo inhibition of elF4GIl cleavage in HeLa cells by Z-VAD-fmk. (A) Inhibition of elF4GIl cleavage in vivo. HeLa cells were pretreated with $75 \mu \mathrm{M} \mathrm{Z}$-VAD-fmk for $1 \mathrm{~h}$ as indicated by + before treatment with $100 \mu \mathrm{M}$ cisplatin, $50 \mu \mathrm{M}$ etoposide, $40 \mathrm{ng} / \mathrm{ml} \mathrm{TNF} \alpha$ plus $10 \mu \mathrm{g} / \mathrm{ml}$ cycloheximide, for $16 \mathrm{~h}$ as indicated on top of the figure. Cell lysates (50 $\mu \mathrm{g}$ of protein) were analyzed on $12 \%$ acrylamide gel and immunoblotted with specific antiserum against $\mathrm{N}$-terminal elF4GII. Lane $\mathrm{C}$, untreated HeLa cells. (B) In vivo inhibition of caspase activity. Cell lysates ( $20 \mu \mathrm{g}$ of protein) as described in $(\mathbf{A})$ were assayed for caspase activity by incubation with Ac-DEVD-pNA (0.2 mM). Release of pNA was analyzed by optical density at $405 \mathrm{~nm}$, and caspase activity is displayed as the number of nanomoles of pNA released per hour per total milligram of protein as calculated from a standard curve by using free pNA. Lane C, untreated HeLa cells 
caspase activation (by greater than $70 \%$ ) observed in cell lysates. Thus, activation of elF4GII cleavage activity correlates with activation of caspases in apoptotic cells, suggesting that caspases are involved in the induction or catalysis of elF4GIl cleavage.

\section{Cleavage of elF4GII in apoptotic K562 and Jurkat cells}

To further address the degree to which elF4GIl cleavage is a general response to apoptosis, we induced apoptosis in two other cell types using a variety of well-characterized inducers. Immunoblot analysis of cell lysates from K562 pre-erythroid leukemia cells (Figure 4A) and Jurkat $T$ cells (Figure 4B) reveal the generation of the same p97 elF4GIl cleavage product observed in HeLa cells, although the degree of cleavage was variable depending on the inducer tested. Treatment of K562 cells with cisplatin, MG132, and to a lesser

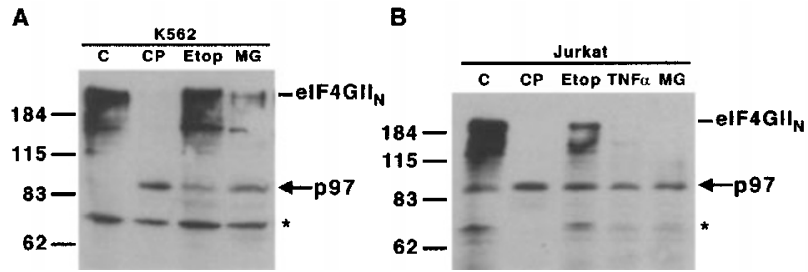

Figure 4 Cleavage of elF4GII in apoptotic K562 and Jurkat cells. K562 cells (A) or Jurkat cells (B) were treated with $100 \mu \mathrm{M}$ cisplatin (CP), $50 \mu \mathrm{M}$ etoposide (Etop), $10 \mu \mathrm{M}$ MG132 (MG), or $40 \mathrm{ng} / \mathrm{ml} \mathrm{TNF} \alpha$ plus $10 \mu \mathrm{g} / \mathrm{ml}$ cycloheximide $(\mathrm{TNF} \alpha)$ as indicated above each lane for $20 \mathrm{~h}$ at $37^{\circ} \mathrm{C}$. Cell lysates were analyzed on $12 \%$ acrylamide gels, transferred to nitrocellulose, and immunoblotted with N-terminal specific elF4GII antibody. elF4GII and cleavage products of elF4GII are indicated by arrows on the right. Asterisks denote an immunoreactive protein of unknown origin often observed in cell lysates from these cells. Molecular weight markers are indicated on the left extent etoposide, or Jurkat cells with cisplatin, MG132, TNF $\alpha$, all effectively induced apoptosis as determined by DNA fragmentation and PARP cleavage (data not shown). Treatment of cells with etoposide resulted in partial activation of apoptosis by these criteria, and also resulted in only partial cleavage of elF4GII. Overall, we observed a good correlation between the per cent apoptotic cells in a population and the degree of elF4GIl cleavage. The p97 putative cleavage fragment was also present in untreated Jurkat cells, suggesting a proportion of apoptotic cells exist in Jurkat cultures as has been reported previously by others (e.g. ${ }^{24}$ ) or another mechanism of elF4GII degradation exists in untreated cells. Overall, these results show that induction of elF4GII cleavage during apoptosis appears to be common to several different cell types and can be induced through several pathways.

\section{In vitro cleavage of elF4GI and elF4GIl by caspases}

To address whether elF4GII is a direct substrate for caspases, we tested a panel of purified caspases for their ability to cleave elF4GII in purified preparations (Figure 5). Preparations of elF4F complex purified from HeLa cells by $m^{7}$ GTP-sepharose affinity chromatography contain both elF4GI and elF4GII, as well as elF4A and elF4E, ${ }^{16}$ and analysis of these preparations by SDS-PAGE and silver stain reveals no observable contamination with other proteins. ${ }^{15}$ Therefore, purified elF4F was incubated with purified caspases and analyzed by immunoblot using the Cterminal-specific antibodies for either elF4GI (Figure 5A) or elF4GII (Figure 5B). The results show elF4GI can be cleaved by caspases 3,8 and 10, however, only caspase 3 produced cleavage fragments of 120 and $46 \mathrm{kDa}$ (arrows) that are also observed in vivo $\left(\mathrm{see}^{15}\right)$. This suggests caspase 3 is primarily responsible for elF4GI cleavage and agrees with our earlier conclusions. ${ }^{15}$ On the other hand, elF4Gll seems to be more

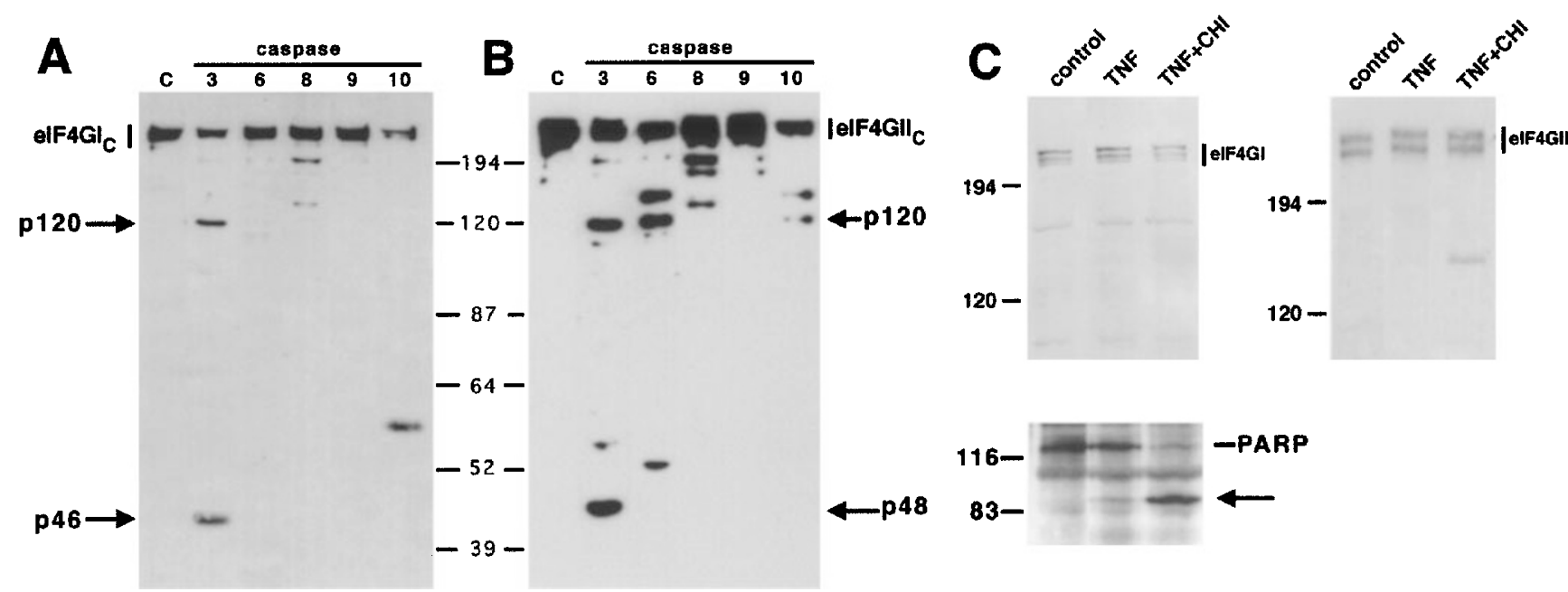

Figure 5 Identification of caspases which can cleave elF4GIl. Purified elF4F was incubated with purified recombinant human caspases 3 , 6 , 8 , 9 , or 10 (10 U each) for $3 \mathrm{~h}$ at $37^{\circ} \mathrm{C}$. Samples were then analyzed on $8 \%$ acrylamide gels and immunoblotted with either antibody specific for $\mathrm{C}$-terminal region of elF4GI (A) or elF4GII (B). Caspase 3 generated cleavage products of elF4GI and elF4GII are indicated by the arrows. The 34 and $28 \mathrm{kDa}$ cleavage products observed in vivo (Figure 2) were not resolved from the solvent front on this gel. (C) MCF7 cells were treated with $40 \mathrm{ng} / \mathrm{ml} \mathrm{TNF} \alpha$ alone or TNF plus $10 \mu \mathrm{g} / \mathrm{ml}$ cycloheximide for $20 \mathrm{~h}$ at $37^{\circ} \mathrm{C}$. Immunoblots of cell lysates were probed with antibody for elF4GI, elF4GII or PARP as indicated. The PARP cleavage product is designated with an arrow 
susceptible to caspase cleavage and cleavage fragments can be produced by caspases 3, 6, 8 and 10 but not caspase 9 . The elF4GIl cleavage patterns generated by each caspase are different, suggesting that each caspase utilizes different cleavage sites on elF4GII, though some may be shared. Although caspase 3 treatment induced cleavage fragments of 120 , and $48 \mathrm{kDa}$ that resemble elF4GIl fragments observed in vivo (Figure 2), it is possible that other caspases are involved in cleavage of elF4GII in vivo since many cleavage products are observed.

To further test if caspase 3 was the predominant elF4GII cleavage activity in vivo, cell extracts from cisplatin-treated HeLa cells were incubated with elF4GII present in initiation factor preparations purified from control cells. A partial elF4GIl cleavage activity was detected upon overnight incubation which was inhibited by addition of DEVD-CHO to lysates (data not shown), supporting a role for caspase 3 in elF4Gll cleavage. To further examine the role of caspase 3, we induced apoptosis in MCF7 breast carcinoma cells which lack caspase 3 via a functional gene deletion. ${ }^{25}$ The data show (Figure $5 \mathrm{C}$ ) that at later stages of apoptosis induced with TNF and cycloheximide, when PARP cleavage is nearly complete, there is no significant cleavage of elF4GI, as has been previously reported. ${ }^{26}$ Likewise, the majority of elF4GII also remained intact in apoptotic MCF7 cells, although one potential cleavage product did appear at low levels. This could represent inefficient cleavage by other caspases (which are also able to cleave PARP $^{25}$ ). Similar efficient PARP cleavage combined with a lack of elF4Gll cleavage was observed when cisplatin was used to induce apoptosis in MCF7 cells (data not shown). Taken together, these results suggest that caspase 3 is the predominant caspase activity which degrades elF4Gll in vivo, but do not exclude ancillary roles of other proteases in elF4GIl processing.

\section{Comparison of caspase 3-induced cleavage of elF4GI and elF4GII}

Since it appeared that caspase 3 could generate elF4GI cleavage products similar to those observed in vivo, we further compared in vitro cleavage of purified elF4GI and elF4GIl present in elF4F preparations by caspase 3 using the C-terminal specific antibodies (Figure 6). Incubation of elF4F with caspase 3 results in rapid cleavage of both elF4GI (Figure 6A) and elF4GIl (Figure 6B), and is complete by $3 \mathrm{~h}$ of incubation at $37^{\circ} \mathrm{C}$. The difference in elF4G cleavage efficiency by caspase 3 as detected here, compared to Figure 5 in which elF4G was not completely cleaved by $3 \mathrm{~h}$, is most likely due to variable activity of caspase 3 preparations. No apparent differences are observed between the efficiency of cleavage of elF4GI and elF4GII and both seem equally susceptible to caspase 3-induced cleavage. Interestingly, caspase 3 generates additional elF4GIl cleavage products containing the antibody epitope than elF4Gl cleavage products (arrows), which indicates recognition of additional cleavage sites on elF4GII. It should be mentioned that both antisera used here are directed against the same region (which is not conserved) of their respective elF4G homolog (aa 1159-1181 of elF4GI, aa 1168-1192 of elF4GII). In conclusion, both elF4GI and elF4GIl can serve as substrates for caspase 3, however, elF4GII is processed into more fragments by caspase 3 than elF4GI.

\section{Analysis of elF4GIl cleavage in vitro}

Characterization of elF4GIl cleavage fragments was further addressed by monitoring a time course of caspase 3 induced cleavage of elF4GII present in HeLa crude initiation factor fragments (Figure 7). Caspase 3 generates p150, and p97 cleavage fragments (Figure 7A) which were recognized by $\mathrm{N}$ terminus specific antibody, similar to the fragments observed above in apoptotic cell lysates. The 150 polypeptide is likely

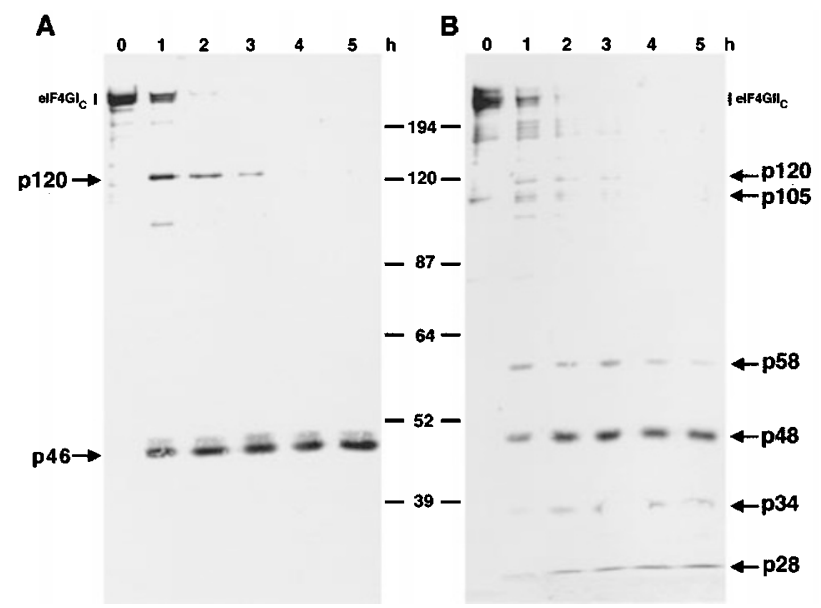

Figure 6 Cleavage of elF4GI and elF4GIl by caspase 3 in vitro. Purified elF4F was incubated with purified recombinant human caspase $3(17 \mathrm{U})$ at $37^{\circ} \mathrm{C}$ and aliquots were taken at time points indicated on top of the figure. Samples were analyzed on $9 \%$ acrylamide gels and immunoblotted with either specific C-terminal elF4GI (A) or elF4GII (B) antibody. Caspase 3 generated cleavage products of elF4GI and elF4GII are indicated by arrows

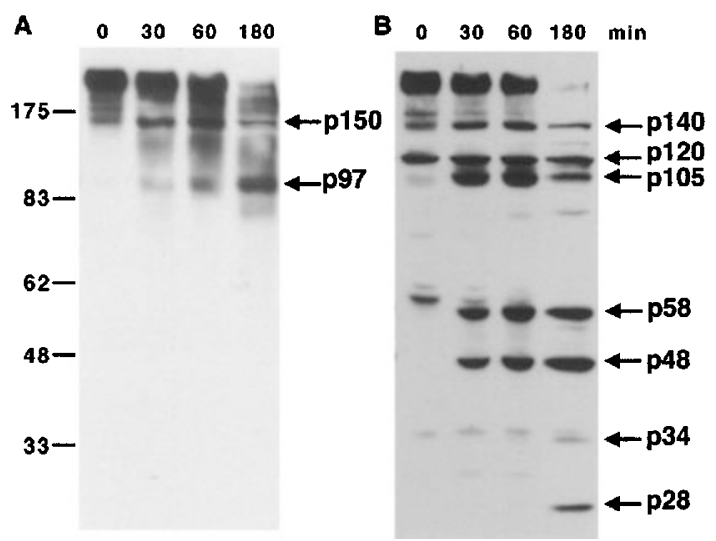

Figure 7 Immunoblot analysis of elF4GII processing scheme in vitro. HeLa RSW $(4 \mu \mathrm{l})$ was incubated at $37^{\circ} \mathrm{C}$ with purified caspase $3(17 \mathrm{U})$ in a total reaction volume of $50 \mu \mathrm{l}$. Time points were taken as indicated above each lane and were analyzed by SDS - PAGE and immunoblotting with either N- (A) or Cterminal (B) specific elF4GII antibody. Caspase 3 generated cleavage products of elF4GI and elF4GII are indicated by arrows. Molecular weight marker is indicated on the left 
to be an intermediate elF4GIl cleavage product, which is further processed by caspase 3 resulting in p97. Analysis of the same samples with C-terminal specific antibody (Figure 7B) reveals generation of several elF4GIl cleavage fragments p140, p105, p58, p48, p34 and p28 which contain the Cterminal antibody epitope. Again, the slower migrating p140, and 105 polypeptides appear to be further processed into the faster migrating end products p58, p48, p34, and p28 as incubation time increased. These results are in good agreement with the cleavage pattern observed in vivo (Figure 2), suggesting that caspase 3 could be responsible for the majority of elF4GIl cleavage observed in vivo.

Analysis of the amino acid sequence of elF4GII reveals four consensus caspase 3 sites (DxxD) ${ }^{27}$ at positions 557560, 848-851, 975-978 and 1159-1162. However, our data presented so far do suggest that other nonconventional caspase 3 sites may actually be utilized by caspase 3. In order to visualize all the caspase 3-generated cleavage products, not just those containing recognizable epitopes, we radiolabeled elF4GII with $\left[{ }^{35} \mathrm{~S}\right]-$ methionine and cysteine by programming rabbit reticulocyte translation lysates with elF4GII mRNA and full-length radiolabeled elF4GIl was purified by affinity chromatography on $\mathrm{m}^{7}$ GTP. sepharose (lanes $a-d$, Figure 8 ) before cleavage reactions were performed. Cap-column purified elF4GIl was then incubated at $37^{\circ} \mathrm{C}$ with purified caspase 3 for the amount of time indicated. Figure 8 (lanes $b-e$ ) shows the cleavage products derived from elF4GII in two independent experiments. Incubation with caspase 3 led to proteolytic processing of elF4GII into multiple cleavage products, some of which appear to be similar to those observed on immunoblots in previous figures, including p97, p58, p48 and p28. Many new bands, previously not seen on immunoblots are also detected here, including p82, p72, p62, p52 and p35, and several proteins which migrate faster than p28. Many of these proteins likely represent cleavage fragments derived from the middle third of elF4GII that are not recognized by the antibodies used in this study but could result from cleavage at classic caspase 3 recognition sites. After extended incubation to $18 \mathrm{~h}$, many bands have disappeared, notably p97 and p58, indicating that both of these can be furthered processed. It is possible that besides the four consensus caspase 3 cleavage sites mentioned above, additional cleavage sites may be used by caspase 3 inefficiently that do not have the classic consensus motif DxxD (see below). Alternatively, slow developing cleavage events could also arise from trace amounts of another protease which could be present in either the caspase preparation or the elF4GII, despite the high level purification of both. In addition, it seems that more polypeptide products are produced from this highly purified substrate than we usually observed in vivo. It is possible that certain cleavage sites on elF4GIl may be masked by the binding of other proteins to elF4GII in vivo that are not present on elF4GII translated in vitro. Alternatively, conformations of elF4GIl may exist when highly purified, which could expose additional sites.

To further identify the origin of some of the cleavage fragments, we purified several C-terminal truncated forms of elF4GIl which were cleaved with caspase 3 . The data

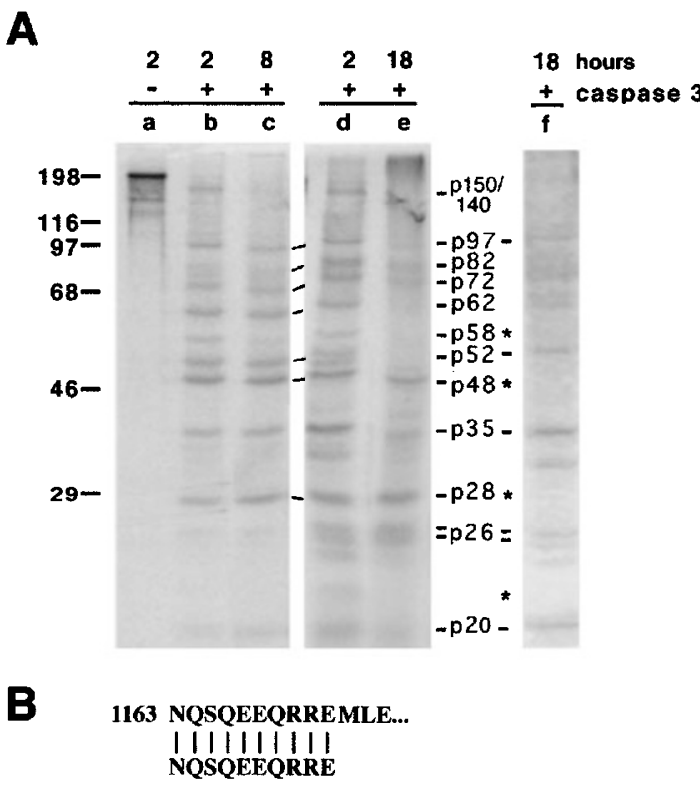

Figure 8 Analysis of processing of purified radiolabeled elF4GIl by caspase 3. (A) In vitro translated elF4GII was purified on methyl-7-GTP-sepharose and eluted with $100 \mu \mathrm{M} \mathrm{m} \mathrm{m}^{7} \mathrm{GTP}$. Purified elF4GIl was incubated with purified caspase $3(17 \mathrm{U})$ and samples were analyzed by SDS-PAGE and autoradiography. Lane $a$, in vitro translated elF4GII (start); lanes b-e, elF4GII incubated with caspase 3 for indicated times. Similarly, truncated elF4GII generated from Spel-linearized cDNA was also purified and cleaved with caspase 3 (lane $\mathrm{f}$ ). Migration of molecular weight markers is indicated on the left; dominant elF4GIl cleavage products are indicated on the right. Asterisks indicate cleavage products of elF4GIl that are not detected when truncated elF4GII (lane f) was used as substrate. (B) Identification of caspase 3 cleavage site. Purified recombinant elF4GII was incubated with purified recombinant caspase 3 for $5 \mathrm{~h}$ at $37^{\circ} \mathrm{C}$, transferred to PVDF, and protein bands were subjected to amino acid sequencing. Resulting amino acid sequence (bottom) was matched with amino acid sequence in elF4GII (top) starting at position 1163

(Figure 8, lane $f$ ) is presented from one such truncated elF4GII (at aa 1126) which reveal p58, p48 and p28 were no longer produced whereas p35, p19 and a p26 doublet was still produced. The p97 fragment was also still visible, although only faintly due to continued processing. These data support the assignment of p58, p48 and p28 fragments to the C-terminal portion of elF4GIl, in agreement with earlier immunoblot data.

In addition, the p28 cleavage fragment was purified and its sequence analyzed by Edman degradation, which revealed a perfect match with the sequence immediately downstream from a consensus caspase cleavage site $D_{L L D}{ }^{1162} \mathrm{~N}$ in the $\mathrm{C}$-terminal region of elF4GIl (Figure $8 \mathrm{~B})$. Although this site is not exactly conserved between elF4GI and elF4GIl, the site is in a similar region of the protein as the downstream elF4GI cleavage site recently identified (see Figure 9). Interestingly, cleavage at position 1162 would result in a C-terminal fragment of approximately $48 \mathrm{kDa}$. Thus, p28 must be generated by additional cleavage of this $\mathrm{C}$-terminal fragment by caspase 3 at a site downstream of 1162 . This site is most likely the sequence IESD at position 1407, which would generate fragments of approximately 28 and $20 \mathrm{kDa}$. 


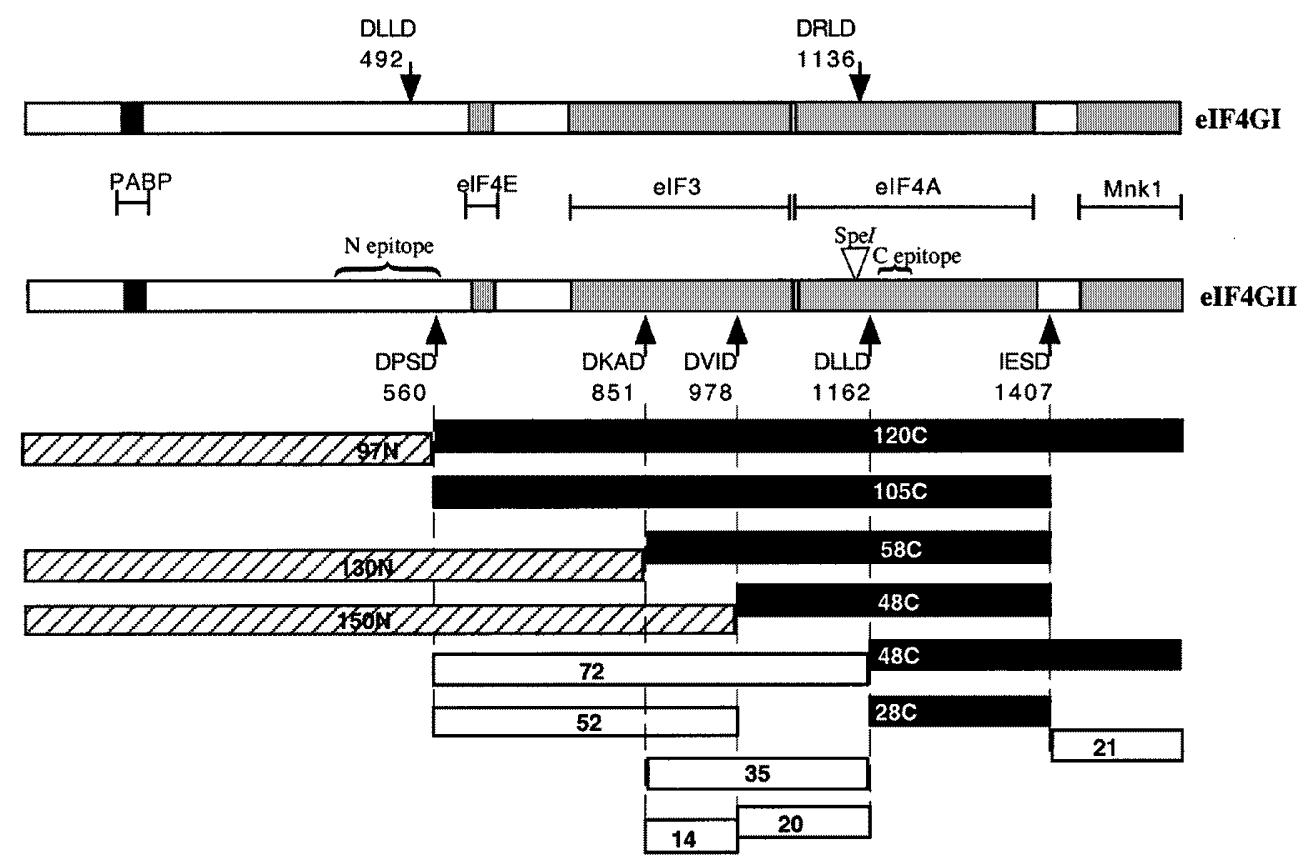

Figure 9 Proposed processing scheme for elF4GII. Previously determined cleavage sites for elF4GI are shown for comparison and bars indicate regions of elF4GI and elF4GII which interact with other factors. The region of elF4GII containing a N-terminus or C-terminus-specific antibody epitope is also shown. Only fragments resulting from cleavage at the four canonical caspase 3 cleavage sites plus the additional IESD site are diagrammed. The putative apparent molecular weight of each fragment is indicated by the number and $\mathrm{N}$ or $\mathrm{C}$ indicate potential reactivity with the respective antisera

\section{Discussion}

Here, we have shown that induction of apoptosis results in rapid and complete cleavage of not only elF4GI, but also elF4GII, and this cleavage occurs concomitantly with the drastic inhibition of cellular translation. Cleavage of elF4GII could be inhibited by Z-VAD-fmk indicating the direct involvement of caspases in the cleavage of elF4GIl as was shown for elF4GI. ${ }^{15}$ In addition, both elF4GI and elF4GII were cleaved by caspase 3 in vitro indicating that caspase 3 could be responsible for the observed elF4G cleavage in vivo. This was further supported by the fact that of the cleavage patterns generated by incubation of purified elF4F with individual purified caspases, caspase 3-generated fragments most closely matched with elF4GIl cleavage products generated in vivo. Both elF4GI and elF4GII play a crucial role in the assembly of the initiation complex and recruitment of ribosomes to capped mRNAs. In poliovirus-infected HeLa cells, it was reported that proteolysis of elF4GII, rather than elF4GI, more closely correlates with translation inhibition in poliovirus- or rhinovirus-infected HeLa cells because its cleavage kinetics lagged significantly behind elF4GI cleavage, especially under experimental conditions which limited viral replication. ${ }^{19,29}$ Further, replenishment of both isoforms of elF4GII in reticulocyte lysates pretreated to cleave endogenous elF4GI and elF4GIl, was capable of restoring cap-dependent mRNA translation, ${ }^{16}$ supporting the hypothesis that translation inhibition in picornavirus-infected cells is primarily mediated by elF4G cleavage. Therefore, the biological importance of elF4G cleavage during apoptosis may also be significant and it is possible that cleavage of both elF4GI and elF4GII may hasten the execution phase of apoptosis. In addition, elF4GI and elF4GIl are cleaved in HeLa cells as well as Jurkat T cells, and K562 cells when treated with a variety of apoptosis-inducing agents as well as in BJAB cells treated with cycloheximide. ${ }^{30}$ Thus, it seems that cleavage of both elF4GI and elF4GII is a common event during apoptosis, supporting an important role for elF4G cleavage in translation shutoff during the execution phase of apoptosis and suggesting that elF4GIl cleavage may be another marker for cell death. Continued investigation of the fate of translation initiation factors during apoptosis has revealed an interesting pattern of proteolysis. Translation factors which are not proteolyzed at all by caspases tested include two other members of the cap-binding protein complex, elF4E, elF4A, most of the subunits of elF3. ${ }^{15,30}$ In contrast, we and others have recently discovered that elF2 $\alpha$ is cleaved at its extreme C-terminus ${ }^{31,32}$ as well as processing of elF4B. ${ }^{30}$ Further experiments are required to determine if execution of apoptosis actually requires any of these cleavage events or drastic inhibition of cellular translation in order to reach completion.

Figure 9 shows a proposed processing scheme which was derived from compiling data from the experiments shown above as well as numerous others which were not shown. To account for all the dominant fragments observed, we hypothesize elF4GIl is cleaved at all four classical caspase 3 cleavage sites (DxxD) at positions 557-560, 848-851, 975-978 and 1159-1162 plus an additional IESD at position 1407. Recently, the caspase 3 cleavage sites on elF4GI were identified ${ }^{28}$ at positions $D_{L L D}{ }^{492} A$, and DRLD ${ }^{1136} R$ (see Figure 9). Although neither of these sites are conserved between elF4GI and elF4GII, the potential caspase 3 cleavage sites $\operatorname{DPSD}^{560} \mathrm{~L}$ and 
DLLD ${ }^{1162} \mathrm{~N}$ are found in similar regions within elF4GIl and could generate a similar tripartite fragmentation of elF4GII, including release of a $48 \mathrm{kDa} \mathrm{C}$-terminal product (which was observed in several experiments). Indeed, we have verified by direct amino acid sequencing that caspase 3 does recognize the DLLD motif at position 1162 (Figure $8 \mathrm{~B})$, however, this sequence was found on a smaller $28 \mathrm{kDa}$ polypeptide, providing strong evidence for processing by caspase 3 at a non-canonical IESD site at position 1407. Since caspase 3 is known to autocatalytically cleave itself at IETD ${ }^{175} \mathrm{~S}$, and is known to cleave other proteins after IETD, ${ }^{33}$ the IESD motif in elF4GII seems a likely candidate. Interestingly, further comparison between eIF4GI and elF4GII reveals that this IESD site is not conserved between the two proteins and no $28 \mathrm{kDa}$ cleavage fragment is generated by caspase 3 -induced cleavage of elF4GI. ${ }^{15}$ The location of antibody epitopes on polypeptide fragments proposed in this processing scheme is consistent with the major fragments observed in our experiments and it also accounts for the dominant cleavage fragments observed using truncated elF4GIl substrates (data not shown). However, several minor fragments which appear late in incubation periods likely result from inefficient cleavage at additional sites not identified here. For instance, p97 which represents the $\mathrm{N}$-terminal third of elF4GIl, was often further degraded during our experiments, particularly during long incubations with highly purified substrate, yet no consensus DxxD caspase sites exist within its sequence. Additional work will be required to confirm this proposed processing scheme and to identify additional sites that are less efficiently recognized by caspase 3. However, it is very clear that elF4GII is cleaved into many more fragments by caspase 3 than elF4GI, ${ }^{28}$ which likely destroys any useful function of elF4GIl fragments in translation.

An interesting question is why elF4Gll is cleaved differently compared to elF4GI. It is not known if elF4GII contains any functions in translation which are slightly different than its homolog. For instance, since large regions of elF4GI and elF4GIl are not homologous, it is possible that elF4GII binds to proteins that do not interact with elF4GI, possibly providing altered or additional functions. Thus, elF4Gll may require a higher degree of proteolytic processing than elF4GI further to inactivate these functions during apoptosis. There is also a possibility that the ordered cleavage of elF4GI and elF4GII might result in a generation of elF4G cleavage fragments that display new properties that might aid in the apoptotic process or the regulation of its induction. It has been shown in the case of poliovirus that upon cleavage, the C-terminal cleavage product of elF4GI can stimulate cap-independent, IRES driven translation. ${ }^{34,35}$ Further, a core region of elF4GI spanning the binding domains for elF4E and elF3 has been shown to be sufficient to support cap-dependent translation. ${ }^{36,37}$ Conceivably, generation of elF4G cleavage products during apoptosis could potentially lead to specific upregulation of certain pro-apoptotic genes due to altered characteristics of elF4GI and elF4GIl cleavage products. Since elF4GI is fragmented into only three portions which releases an intact core domain, whereas elF4GII is fragmented into five or more segments which destroys the core domain, it is more likely that gained functions would reside with elF4GI fragments than elF4GIl fragments. However, further studies are required to test these new hypotheses and more finely assess the exact impact of elF4G cleavage on the apoptotic process.

\section{Materials and Methods}

\section{Cell culture}

HeLa S3 cell monolayers were grown in S-MEM (Irvine Scientific), Jurkat and K562 cells were grown in RPMI (Irvine Scientific) supplemented with $10 \%$ bovine calf serum, $0.5 \%$ fetal calf serum (Summit Biotech.), $100 \mathrm{U}$ penicillin and $100 \mu \mathrm{g}$ streptomycin per $\mathrm{ml}$ (Sigma) in a humidified chamber containing $5 \% \mathrm{CO}_{2}$. For the induction of apoptosis, various concentrations of cisplatin, etoposide, cycloheximide (Sigma), MG132 (Calbiochem), TNF $\alpha$ (Peprotech), stock solutions were diluted with S-MEM and then incubated with cells at $37^{\circ} \mathrm{C}$ for the time indicated in each figure. For in vivo inhibition experiments cells were first preincubated with the cell-permeable caspase inhibitor Z-VAD-fmk (Enzyme Systems Products) at indicated concentrations for $1 \mathrm{~h}$ at $37^{\circ} \mathrm{C}$ before the cisplatin was added to the cell cultures.

\section{Antibodies}

Antibodies for elF4GI ${ }^{15,20}$ and elF4GII ${ }^{14,16}$ have been previously described. Immunoblot analysis for PARP cleavage was performed as previously described ${ }^{15}$ using a monoclonal anti-PARP antibody (Zymed Labs). Levels of PARP cleavage were quantitated from scanned immunoblots using NIH Image software.

\section{Preparation of HeLa cell extracts}

Cell extracts were prepared as described. ${ }^{15}$ Briefly, HeLa cells were washed with phosphate-buffered saline (PBS), resuspended in CHAPS lysis buffer (20 mM Tris pH 7.2, 0.1 M NaCl, $1 \mathrm{mM}$ EDTA, $10 \mathrm{mM}$ DTT, 0.5\% 3-[(3-cholamidopropyl)dimethyl-ammonio]-1-propanesulfonate (CHAPS) (Research Organics), 10\% sucrose) and incubated on ice for $30 \mathrm{~min}$. Cell lysates were then centrifuged for 10 min at $10000 \times g$ at $4^{\circ} \mathrm{C}$, supernatants were collected and stored at $-80^{\circ} \mathrm{C}$.

\section{Metabolic labeling of proteins}

After treatment of the cells with apoptosis inducers as indicated in the figures, the medium was replaced with methionine depleted medium $(1 \mathrm{ml})$, and cells were pulse-labeled with $27 \mu \mathrm{Ci} \operatorname{Tran}^{35} \mathrm{~S}$ (ICN) for $1 \mathrm{~h}$ at selected time points. Cytoplasmic extracts were prepared as described above and then analyzed (50 $\mu \mathrm{g}$ of protein) by SDS-PAGE and autoradiography with Kodak Biomax MR film.

\section{Caspase assays}

Cell lysates were analyzed for caspase activity using the colorimetric peptide substrate Ac-DEVD-pNA (acetyl-DEVD-para-nitroanilide) (Quality Controlled Biochemicals). Assays $(0.1 \mathrm{ml})$ contained $20 \mu \mathrm{g}$ of total protein from samples indicated in the figure legends and $0.2 \mathrm{mM}$ pNA substrate (final concentration). Samples were incubated for $2 \mathrm{~h}$ at $37^{\circ} \mathrm{C}$ and release of pNA was monitored at $405 \mathrm{~nm}$ using a Beckman DU-70 UV Spectrophotometer. 


\section{Expression and purification of caspases}

The full length cDNAs encoding human caspases 3, 6, 9, and the cDNAs encoding caspase 8 (Ser-217 to Asp-479) and caspase 10 (Ile162 to lle-479) ${ }^{21}$ cloned into pET15b (caspase 8), pET21b (caspases $6,9,10$ ) and $\mathrm{pET} 23 \mathrm{~b}$ (caspase 3) (all Novagen) were expressed in Escherichia coli BL21(DE3)pLysS. Caspases 3 and 8 were a kind gift of Dr. Claudius Vincenz; caspases 6, 9 and 10 were a kind gift of Dr. Emad Alnemri. The expressed proteins were purified by affinity chromatography on TALON metal affinity resin (Clontech) according to the manufacturer's instructions. Working concentrations of active caspases were standardized based on in vitro colorimetric cleavage assays using appropriate substrate peptides coupled to paranitroanilide (pNA). Caspase activity units are defined as the amount of caspase required to hydrolyze $1 \mathrm{nmol}$ pNA substrate per minute. Various caspases were used in cleavage reactions at concentrations ranging from $10-60 \mu \mathrm{g} / \mathrm{ml}$ as determined appropriate by these assays.

\section{Purification of elF4F and elF4GII}

elF4F was purified from spinner HeLa cells as described. ${ }^{22}$ In short, a ribosomal salt wash preparation (RSW) $(2 \mathrm{ml})$ was loaded on a 15$30 \%$ sucrose gradient in buffer $\mathrm{F}(20 \mathrm{mM}$ Hepes $\mathrm{pH} 7.6,0.5 \mathrm{M} \mathrm{KCl}$, $0.5 \mathrm{mM}$ EDTA, $2 \mathrm{mM} \beta$-mercaptoethanol), and centrifuged for $18 \mathrm{~h}$ at $3^{\circ} \mathrm{C}$ in a Beckman SW28 rotor. Fractions $(1 \mathrm{ml})$ were collected and analyzed by immunoblot for the presence of elF4F. Fractions containing elF4F were pooled, diluted four-fold with buffer $\mathrm{A}(20 \mathrm{mM}$ Mops pH 7.6, $0.25 \mathrm{mM}$ DTT, $0.1 \mathrm{mM}$ EDTA, $50 \mathrm{mM} \mathrm{NaF}, 10 \%$ glycerol), and loaded onto a 7-Methyl GTP-Sepharose 4B column (Pharmacia) equilibrated in buffer $\mathrm{B} 110$ (buffer A plus $110 \mathrm{mM} \mathrm{KCl}$ ). elF4F was eluted from the column with buffer B110 plus $\mathrm{m}^{7}$ GTP $(70 \mu \mathrm{M})$ and fractions were analyzed by Coomassie stain.

Purification of in vitro translated elF4GII was carried out by mixing in vitro translated elF4GII $(50 \mu \mathrm{l})$ with $100 \mu \mathrm{l} \mathrm{m} \mathrm{m}^{7}$ GTP sepharose beads equilibrated in buffer B110. After incubation for $1 \mathrm{~h}$ at room temperature, the beads were washed with $1.5 \mathrm{ml}$ buffer $\mathrm{B} 110$, and bound proteins were eluted with $100 \mu \mathrm{M} \mathrm{m} \mathrm{m}^{7}$ GTP in buffer B110.

\section{Plasmid constructs}

pcDNA3-HA-4GII was constructed as described. ${ }^{23}$ The plasmid was linearized with $X$ mal to generate full-length elF4GII via in vitro transcription, purified by phenol/chloroform extraction, and concentrated by alcohol precipitation for further use in transcription reactions.

\section{Transcription and translation}

Transcription reactions for elF4GII using T7 RNA polymerase (Promega) were carried out according to manufacturer's recommendations followed by purification of the RNA using spin columns (Eppendorf-5 Prime). Translation reactions were performed in rabbit reticulocyte lysate (RRL) (Promega) according to the manufacturer's recommendations in a $50 \mu \mathrm{l}$ reaction volume and incubated for $90 \mathrm{~min}$ at $30^{\circ} \mathrm{C}$. Samples $(2 \mu \mathrm{l})$ were subjected to SDS-PAGE and analyzed by autoradiography or otherwise, used to purify the in vitro translated elF4GII as described above. C-terminal truncated forms of elF4GII were synthesized by linearizing plasmid DNA at restriction sites within the elF4GIl open reading frame (Spel or Xhol) followed by transcription and translation in vitro. Truncated radiolabeled elF4GII was purified by cap affinity chromatography as described above before analysis.

\section{Amino acid sequencing}

To determine the caspase 3 cleavage site on elF4GII, purified baculovirus-expressed elF4GII (approximately $40 \mu \mathrm{g}$ ) was incubated with purified caspase 3 for $5 \mathrm{~h}$ at $37^{\circ} \mathrm{C}$, loaded onto $15 \%$ acrylamide gel, and blotted to polyvinylidene fluoride (PVDF). Blot was stained briefly with Coomassie stain, destained briefly, and the protein band was cut out and subjected to Edman degradation at the Protein Chemistry Core Facility, Baylor College of Medicine.

\section{Acknowledgements}

This work was supported by National Institutes of Health Grants Al27914 and GM59803 (to RE Lloyd) and the Medical Research Council of Canada (N Sonenberg).

\section{References}

1. Martin SJ, Lennon SV, Bonham AM and Cotter TG (1990) Induction of apoptosis (programmed cell death) in human leukemic $\mathrm{HL}-60$ cells by inhibition of RNA or protein synthesis. J. Immunol. 145: 1859-1867

2. Piedrafita FJ and Pfahl M (1997) Retinoid-induced apoptosis and Sp1 cleavage occur independently of transcription and require caspase activation. Mol. Cell. Biol. 17: 6348-6358

3. He AW and Cory JG (1999) p53-independent anisomycin induced G1 arrest and apoptosis in L1210 cell lines. Anticancer Res. 19: 421-428

4. Tang D, Lahti JM, Grenet J and Kidd VJ (1999) Cycloheximide-induced T-cell death is mediated by a Fas-associated death domain-dependent mechanism. J. Biol. Chem. 274: 7245-7252

5. Ahn YH, Kim YH, Hong SH and Koh JY (1998) Depletion of intracellular zinc induces protein synthesis-dependent neuronal apoptosis in mouse cortical culture. Exp. Neurol. 154: 47-56

6. Coxon FP, Benford HL, Russell RG and Rogers MJ (1998) Protein synthesis is required for caspase activation and induction of apoptosis by bisphosphonate drugs. Mol. Pharmacol. 54: 631-638

7. Goering PL, Thomas D, Rojko JL and Lucas AD (1999) Mercuric chlorideinduced apoptosis is dependent on protein synthesis. Toxicol. Lett. 105: 183195

8. Schulz JB, Weller M and Klockgether T (1996) Potassium deprivation-induced apoptosis of cerebellar granule neurons: a sequential requirement for new mRNA and protein synthesis, ICE-like protease activity, and reactive oxygen species. J. Neurosci. 16: 4696-4706

9. Lamphear BJ, Kirchweger R, Skern T and Rhoads RE (1995) Mapping of functional domains in eukaryotic protein synthesis initiation factor $4 G$ (elF4G) with picornaviral proteases - Implications for cap-dependent and capindependent translational initiation. J. Biol. Chem. 270: 21975-21983

10. Morley SJ, Curtis PS and Pain VM (1997) elF4G - Translation's mystery factor begins to yield its secrets [Review]. RNA 3: 1085-1104

11. Etchison D, Milburn SC, Edery I, Sonenberg N and Hershey JWB (1982) Inhibition of HeLa cell protein synthesis following poliovirus infection correlates with the proteolysis of a 220,000-dalton polypeptide associated with eukaryotic initiation factor 3 and a cap binding protein complex. J. Biol. Chem. 257: 1480614810

12. Devaney MA, Vakharia VN, Lloyd RE, Ehrenfeld E and Grubman MJ (1988) Leader protein of foot-and-mouth disease virus is required for cleavage of the p220 component of the cap-binding protein complex. J. Virol. 62: 4407-4409

13. Belsham GJ and Sonenberg N (1996) RNA-Protein interactions in regulation of picornavirus RNA translation. Microbiol. Rev. 60: 499-511

14. Goldstaub D, Gradi A, Bercovitch Z, Grosmann Z, Nophar Y, Luria S, Sonenberg N and Kahana C (2000) Poliovirus 2A protease induces apoptotic cell death. Mol. Cell. Biol. 20: 1271-1277

15. Marissen WE and Lloyd RE (1998) Eukaryotic translation initiation factor $4 G$ is targeted for proteolytic cleavage by caspase 3 during inhibition of translation in apoptotic cells. Mol. Cell. Biol. 18: 7565-7574 
16. Gradi A, Imataka H, Svitkin YV, Rom E, Raught B, Morino S and Sonenberg N (1998) A novel functional human eukaryotic translation initiation factor 4G. Mol. Cell. Biol. 18: 334-342

17. Goyer C, Altmann M, Lee HS, Blanc A, Deshmukh M, Woolford JL, Trachsel H and Sonenberg N (1993) TIF4631 and TIF4632 - 2 yeast genes encoding the High-molecular-weight subunits of the cap-binding protein complex (Eukaryotic initiation Factor-4F) contain an RNA recognition motif-like sequence and carry out an essential function. Mol. Cell. Biol. 13: 4860-4874

18. Allen ML, Metz AM, Timmer RT, Rhoads RE and Browning KS (1992) Isolation and sequence of the CDNAs encoding the subunits of the isozyme form of wheat protein synthesis initiation Factor-4F. J. Biol. Chem. 267: 23232-23236

19. Gradi A, Svitkin YV, Imataka H and Sonenberg N (1998) Proteolysis of human eukaryotic translation initiation factor elF4GII, but not elF4GI, coincides with the shutoff of host protein synthesis after poliovirus infection. PNAS 95: 1108911094

20. Raught B, Gingras A-C, Gygi SP, Imataka H, Morino S, Gradi A, Aebersold Rand Sonenberg N (2000) Serum-stimulated, rapamycin-sensitive phosphorylation sites in the eukaryotic translation initiation factor 4GI. EMBO J. 19: 434-444

21. Fernandes-Alnemri T, Armstrong RC, Krebs J, Srinivasula SM, Wang L, Bullrich F, Fritz LC, Trapani JA, Tomaselli KJ, Litwack G and Alnemri ES (1996) In vitro activation of CPP32 and Mch3 by Mch4, a novel human apoptotic cysteine protease containing two FADD-like domains. PNAS 93: 7464-7469

22. Lamphear BJ and Panniers R (1990) Cap binding protein complex that restores protein synthesis in heat-shocked Ehrlich cell lysates contains highly phosphorylated elF-4E. J. Biol. Chem. 265: 5333-5336

23. Imataka H, Gradi A and Sonenberg N (1998) A newly identified N-terminal amino acid sequence of human elF4G binds poly(A)-binding protein and functions in poly(A)-dependent translation. EMBO J. 17: 7480-7489

24. Kurita-Ochiai T, Fukushima K and Ochiai K (1997) Butyric acid-induced apoptosis of murine thymocytes, splenic $T$ cells, and human Jurkat $T$ cells. Infection Immunity 65: 35-41

25. Janicke RU, SprengartML, Wati MR and Porter AG (1998)Caspase-3 is required for DNA fragmentation and morphological changes associated with apoptosis. Journal of Biological Chemistry 273: 9357-9360

26. Bushell M, McKendrick L, Janicke RU, Clemens MJ and Morley SJ (1999) Caspase-3 is necessary and sufficient for cleavage of protein synthesis eukaryotic initiation factor $4 \mathrm{G}$ during apoptosis. FEBS Lett. 451: 332-336
27. Talanian RV, Quinlan C, Trautz S, Hackett MC, Mankovich JA, Banach D, Ghayur T, Brady KD and Wong WW (1997) Substrate specificities of caspase family proteases. J. Biol. Chem. 272: 9677-9682

28. Bushell M, Poncet D, Marissen WE, Lloyd RE, Flotow H, Clemens MJ and Morley SJ (1999) Cleavage of polypeptide chain initiation factor elF4GI during apoptosis: Characterisation of an internal fragment generated by caspase-3mediated cleavage. Cell Death Diff: 7: 628-636

29. Svitkin YV, Gradi A, Imataka H, Morino S and Sonenberg N (1999) Eukaryotic Initiation Factor 4GII (elF4GII), but Not elF4GI, Cleavage Correlates with Inhibition of Host Cell Protein Synthesis after Human Rhinovirus Infection. J. Virol. 73: 3467-3472

30. Bushell M, Wood W, Clemens M and Morley S (2000) Changes in integrity and association of eukaryotic protein synthesis initiation factors during apoptosis. Eur. J. Biochem. 267: 1083-1091

31. Marissen W, Guo Y, Thomas A, Matts R and Lloyd R (2000) Identification of caspase 3-mediated cleavage and functional alteration of eukaryotic initiation factor 2 $\alpha$ in apoptosis. J. Biol. Chem. 275: 9314-9323

32. Satoh S, Hijikata M, Handa H and Shimotohno K (1999) Caspase-mediated cleavage of eukaryotic translation initiation factor subunit $2 \alpha$. Biochem. J. 342 $65-70$

33. Rheaume E, Cohen LY, Uhlmann F, Lazure C, Alam A, Hurwitz J, Sekaly PP and Denis $F(1997)$ The large subunit of replication factor c is a substrate for caspase3 in vitro and is cleaved by a caspase-3-like protease during fas-mediated apoptosis. EMBO J. 16: 6346-6354

34. Borman AM, Kirchweger R, Ziegler E, Rhoads RE, Skern T and Kean KM (1997) elF4G and its proteolytic cleavage products: effect on initiation of protein synthesis from capped, uncapped, and IRES-containing mRNAs. RNA 3: 186 196

35. OhImann T, Rau M, Pain VM and Morley SJ (1996) The c-terminal domain of eukaryotic protein synthesis initiation factor (eIF) $4 \mathrm{G}$ is sufficient to support capindependent translation in the absence of elF4E. EMBO J. 15: 1371-1382

36. De Gregorio E, Preiss T and Hentze MW (1999) Translation driven by an elF4G core domain in vivo. EMBO J. 18: 4865-4874

37. Morino S, Imataka H, Svitkin YV, Pestova TV and Sonenberg N (2000) Eukaryotic translation initiation factor $4 \mathrm{E}$ (elF4E) site and the middle one-third of elF4GI constitute the core domain for cap-dependent translation, and the Cterminal on-third functions as modulatory region. Mol. Cell. Biol. 20: 468-477 